\title{
Legal Disharmony in Indonesia
}

\author{
Henry Sinaga ${ }^{1}$, \\ Prof.Dr.SyafruddinKalo,SH,Mhum ${ }^{2}$,Prof.Dr.Runtung,SH,Mhum ${ }^{3}$, \\ Prof.Dr.Suhaidi, $\mathrm{SH}, \mathrm{MH}^{4}$, \\ ${ }^{1}$ Post-Graduate, University of North Sumatera, Indonesia \\ ${ }^{2}$ Promotor, University of North Sumatera, Indonesia \\ ${ }^{3}$ co-Promotor, University of North Sumatera, Indonesia \\ ${ }^{4}$ co-Promotor, University of North Sumatera, Indonesia
}

\begin{abstract}
Nowadays there is a legal disharmony concerning natural resources in Indonesia. It is found in some laws regarding natural resources. There are 12 (twelve) laws on natural resources in Indonesia which are inharmonious, overlapping, and contradictory one to another. This legal disharmony has brought negative impacts such as destructions and degrading natural resources, conflicts related to natural resources, legal and social problems, riot in legal system, legal uncertainty, and injustice to the society. The legal disharmony in the natural resources management in Indonesia is caused by the laws regulating the management of the natural resources in Indonesia that do not apply the same principles even though they have the same object and legal resources. New legislation functioning as the umbrella of laws or the main body for regulations of the natural resource management in Indonesia needs to be set in order to solve the problems of the legal disharmony in the management of Indonesian natural resources.
\end{abstract}

Keywords - Disharmony, Law, Indonesia

\section{INTRODUCTION}

MPR RI (People's Consultative Assembly of the Republic of Indonesia) on November 9, 2001, issued a decree to the President of the Republic of Indonesia and DPR RI (Parliament of the Republic of Indonesia) as the authorized institutions to enact the Laws in Indonesia; so that a review be made to the prevailing laws concerning the management of Indonesian natural resources in synchrozing the inter-sector policies to realize the laws and regulations which are based on the Principles of Agrarian Reform and Management of Natural Resources enacted by MPR RI. ${ }^{1}$ In addition, MPR RI also assigns the President and DPR RI torevoke, amend and/or replace all regulations which are not in accordance with the Decree of MPR RI. ${ }^{2}$ This Decree of MPR RI is restated in the Decree of MPR RI No.5/MPR/2003 on Assignment to the Head of MPR RI to offer Suggestions to the Report on the Implementation of the Decision of MPR RI by the President, DPR, BPK, MA in the Annual Meeting of MPR RI in 2003, in which MPR RI suggested that the Presiden together with DPR RI discuss the laws on the management of natural resources that will function as the main laws. ${ }^{3}$ The Decree of MPR RI to the Presiden and DPR RI to review and establish the law which will function as the main body for the regulations of the management of Indonesian natural resources is issued by MPR RI under the considerations that the laws and regulations related to the management of the natural resources in Indonesia are overlapping and cotradictive or disharmonious. ${ }^{4}$

\section{FINDING OF DISHARMONY IN 12 (TWELVE) LAWS.}

According to the study by the Compiler Team affiliated in ESP (Environmental Sector Program) 2 of the State Ministry of Environmental Affairs and DANIDA consisting of Maria S.W. Sumardjono, Nurhasan Ismail, Ernan Rustiadi, and Abdullah Aman Damai, there are 12 (twelve) laws on the management of the natural resources in Indonesia which are inharmonious, overlapping and contradictory or disharmony one to another. The 12 (twelve) laws are the Law No. 5/1960 on Land Act, the Law No. 4/2009 on Mineral and Coal Mining, the Law No. 5/1990 on Vital Natural Resource Conservation and Its Ecosystem, the Law No. 23/1997 on Environment Management (Revised by the Law No. 32/2009 on the Environmeantal Protection and Management), the Law No. 41/1999 on Forestry, the Law No. 22/2001 on Petroleum and Natural Gas, the Law No. 27/2003 on Earth Heat, the Law No. 7/ 2004 on Water Resources, the Law No. 31/2004 on Fishery, the Law No. 26/2007 Spatial Layout, the Law No. 27/ 2007 on the Management of Coastal Areas and Small Islands, and the Law No. 18/2008 on the Management of Garbage. ${ }^{5}$ In normative level, this disharmony occured either horizontally (in the same level of laws and regulations) or vertically (in the hierarchical/ranked laws). ${ }^{6}$ 


\section{DESCRIPTON OF THE LAWS IN DISHARMONY.}

The following table illustrates the comparison between the Law No. No. 5/1960 on Land Acts or what is also called UUPA and the Law No. 41/ 1999 on Forestry or in short UU Kehutanan (Forestry Law), study results from the Compiler Team who are affiliated in ESP 2 of the State Ministry of Environmental Affairs and DANIDA; for example, the disharmony in the laws on the management of the natural resources in Indonesia is described by 7 (seven) criteria or yardsticks; namely 1) orientation (exploitation or conservation), 2) partiality (pro-society, atau pro-capital), 3) management (centralism/decentralism, attitude towards legal pluralism) and its implementation (sectoral, coordination, orientation to production), 4) Human Rights Protection (gender, recognition of MHA (Customary Law Community), dispute settlement), 5) Good governance administration (participation, transparency and accountability), 6) the relationships between people and SDA (Natural Resources) (Title atau Permit) and 7) Relationship between the state and SDA.

\section{TABLE 1 : COMPARISON BETWEEN UUPA (LAND ACT) AND FORESTRY LAW}

\begin{tabular}{|c|c|c|c|c|c|c|c|c|}
\hline \multirow[b]{2}{*}{$\begin{array}{l}\text { Legis } \\
\text { lation }\end{array}$} & \multicolumn{7}{|c|}{ Yardstick } & \multirow{2}{*}{$\begin{array}{c}\text { SDA } \\
\text { Group }\end{array}$} \\
\hline & $\begin{array}{l}\text { Orientat } \\
\text { ion } \\
\text { (exploit } \\
\text { ation or } \\
\text { conserv } \\
\text { ation) }\end{array}$ & $\begin{array}{l}\text { Pratialit } \\
\text { y (pro- } \\
\text { society } \\
\text { or pro- } \\
\text { capital) }\end{array}$ & $\begin{array}{l}\text { Managemen } \\
\mathrm{t} \\
\text { (centralistis } \\
\mathrm{m} / \text { decentrali } \\
\text { stism, } \\
\text { attitude } \\
\text { toward legal } \\
\text { pluralism) } \\
\text { and its } \\
\text { implementat } \\
\text { ion } \\
\text { (coordinatio } \\
\mathrm{n} \text { sectoral, } \\
\text { production } \\
\text { orientation) }\end{array}$ & $\begin{array}{l}\text { Human } \\
\text { Rights } \\
\text { Protectio } \\
\mathrm{n} \\
\text { (gender, } \\
\text { recogniti } \\
\text { on of } \\
\text { MHA } \\
\text { (Custom } \\
\text { ary Law } \\
\text { Commun } \\
\text { ity), } \\
\text { dispute } \\
\text { settleme } \\
\text { nt ) }\end{array}$ & $\begin{array}{l}\text { Good } \\
\text { governan } \\
\text { ce } \\
\text { Administ } \\
\text { ration(pa } \\
\text { rticipatio } \\
\text { n, } \\
\text { transpare } \\
\text { ncy and } \\
\text { accounta } \\
\text { bility) }\end{array}$ & $\begin{array}{l}\text { Relations } \\
\text { hip } \\
\text { between } \\
\text { people } \\
\text { and SDA } \\
\text { (Title or } \\
\text { Permit) }\end{array}$ & $\begin{array}{l}\text { Relation } \\
\text { ship } \\
\text { between } \\
\text { the state } \\
\text { and SDA }\end{array}$ & \\
\hline $\begin{array}{l}\text { Law } \\
\text { No. } \\
5 / 196 \\
0 \text { on } \\
\text { Land } \\
\text { Act }\end{array}$ & $\begin{array}{l}\text { Conser } \\
\text { vation } \\
\text { (Article } \\
\text { 15), } \\
\text { Nationa } \\
\text { lism } \\
\text { (Article } \\
9(1) 21 \\
(1))\end{array}$ & 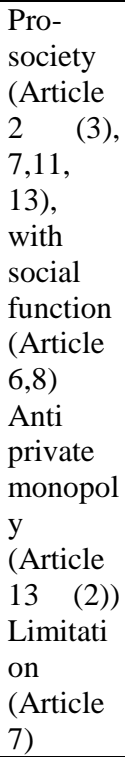 & $\begin{array}{l}\text { Centralistis } \\
\mathrm{m} \text { (Article 2 } \\
\text { (1) and } \\
\text { Explanation } \\
\text { ), } \\
\text { accommodat } \\
\text { e legal } \\
\text { pluralisme } \\
\text { (Article } 3 \\
\text { and 5) there } \\
\text { is } \\
\text { medebewind } \\
\text { (Article } 2 \\
\text { (4)) } \\
\text { Coordinatio } \\
\mathrm{n} \\
\text { integration } \\
\text { (Article } \\
1,4,8)\end{array}$ & 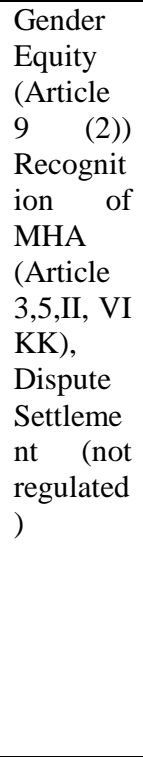 & $\begin{array}{l}\text { Not } \\
\text { regulated }\end{array}$ & $\begin{array}{l}\text { Title } \\
\text { (Article } \\
4 \text { and 16, } \\
20-48 \text { ) }\end{array}$ & $\begin{array}{l}\text { HMN } \\
\text { (Rights } \\
\text { of } \\
\text { Control } \\
\text { by the } \\
\text { State) } \\
\text { (Article } \\
\text { 2) } \\
\text { State } \\
\text { Land } \\
\text { Village } \\
\text { Adat } \\
\text { Land } \\
\text { Titled } \\
\text { Land }\end{array}$ & $\begin{array}{l}\text { SDA } \\
\text { includes } \\
\text { the group } \\
\text { of: } \\
\text { Earth } \\
\text { surface } \\
\text { and body } \\
\text { with } \\
\text { everythin } \\
\text { g beneath } \\
\text { the water, } \\
\text { hinterland } \\
\text { waters or } \\
\text { sea, outer } \\
\text { space } \\
\text { above the } \\
\text { Earth and } \\
\text { water. }\end{array}$ \\
\hline
\end{tabular}


Legal Disharmony in Indonesia

\begin{tabular}{|c|c|c|c|c|c|c|c|c|}
\hline \multirow[b]{2}{*}{$\begin{array}{c}\text { Legislat } \\
\text { ion }\end{array}$} & \multicolumn{7}{|c|}{ Yardstick } & \multirow[t]{2}{*}{ SDA Group } \\
\hline & $\begin{array}{l}\text { Orientati } \\
\text { on } \\
\text { (exploita } \\
\text { tion or } \\
\text { conserva } \\
\text { tion) }\end{array}$ & $\begin{array}{l}\text { Pratiality } \\
\text { (pro- } \\
\text { society } \\
\text { or pro- } \\
\text { capital) }\end{array}$ & $\begin{array}{l}\text { Management } \\
\text { (centralistism/de } \\
\text { centralistism, } \\
\text { attitude toward } \\
\text { legal pluralism) } \\
\text { and its } \\
\text { implementation } \\
\text { (coordination } \\
\text { sectoral, } \\
\text { production } \\
\text { orientation) }\end{array}$ & $\begin{array}{l}\text { Human } \\
\text { Rights } \\
\text { Protection } \\
\text { (gender, } \\
\text { recognition } \\
\text { of MHA } \\
\text { (Customary } \\
\text { Law } \\
\text { Community), } \\
\text { dispute } \\
\text { settlement ) }\end{array}$ & $\begin{array}{l}\text { Good } \\
\text { governanc } \\
e \\
\text { Administr } \\
\text { ation(parti } \\
\text { cipation, } \\
\text { transparen } \\
\text { cy and } \\
\text { accountab } \\
\text { ility) }\end{array}$ & $\begin{array}{l}\text { Relationship between } \\
\text { people and SDA (Title } \\
\text { or Permit) }\end{array}$ & $\begin{array}{l}\text { Relation } \\
\text { ship } \\
\text { between } \\
\text { the state } \\
\text { and SDA }\end{array}$ & \\
\hline $\begin{array}{l}\text { Law } \\
\text { N0. } \\
41 / 199 \\
9 \text { on } \\
\text { Forestr } \\
\text { y }\end{array}$ & $\begin{array}{l}\text { Balance } \\
\text { dexploit } \\
\text { ation and } \\
\text { conserva } \\
\text { tion } \\
\text { ("Consid } \\
\text { ering" } \\
\text { and } \\
\text { General } \\
\text { Provisio } \\
\text { nal) } \\
\text { Exploitat } \\
\text { ion } \\
\text { (Article } \\
\text { 23-39) } \\
\text { Conserv } \\
\text { ation } \\
\text { (Article } \\
40-51 \text { ) }\end{array}$ & $\begin{array}{l}\text { Pro- } \\
\text { society } \\
\text { in } \\
\text { Konsider } \\
\text { ans } \\
\text { "“Consid } \\
\text { ering" } \\
\text { and } \\
\text { Public } \\
\text { Provisio } \\
\text { nal) but } \\
\text { pro- } \\
\text { capital in } \\
\text { substanc } \\
\mathrm{e} \\
\text { (Article } \\
27-32 \text { ) }\end{array}$ & $\begin{array}{l}\text { Centralistic, } \\
\text { region is only } \\
\text { operational } \\
\text { (Article } 4 \text { (1), } \\
\text { (2), 66, Public } \\
\text { Provisional). } \\
\text { Legal Pluralism } \\
\text { (not regulated). } \\
\text { Sectoral (Ps } 4 \text {, } \\
6,7,8 \text { etc. Public } \\
\text { Provisional); } \\
\text { specific } \\
\text { production } \\
\text { orientation }\end{array}$ & $\begin{array}{l}\text { Gender } \\
\text { Equity (not } \\
\text { regulated), } \\
\text { MHA } \\
\text { Recognition } \\
\text { (only } \\
\text { "noticing the } \\
\text { rghts of } \\
\text { MHA") } \\
\text { Customary } \\
\text { Forest is } \\
\text { classified } \\
\text { into state } \\
\text { forest) } \\
\text { (Article 4(3), } \\
5,17 \text { (2), } \\
\text { 37,67, Public } \\
\text { Provisional), } \\
\text { Dispute } \\
\text { Settlement } \\
\text { (Article } 74- \\
76 \text { ) }\end{array}$ & $\begin{array}{l}\text { Participati } \\
\text { on, } \\
\text { Transpare } \\
\text { ncy, } \\
\text { Accounta } \\
\text { bility } \\
\text { (Article 2, } \\
11(2), 42 \\
(2), 60 \\
(2), 62, \\
64,68-70, \\
\text { Public } \\
\text { Provision } \\
\text { a1), there } \\
\text { is } \\
\text { representa } \\
\text { tive } \\
\text { complaint } \\
\text { (Article } \\
71-73 \text { ) }\end{array}$ & $\begin{array}{l}\text { Permit (Article 26-32, } \\
\text { Public Provisional), } \\
\text { Permit of loan } \\
\text { agreement (Article } 38 \\
\text { (2) and (5)), for } \\
\text { example: business } \\
\text { permit to utilize forest } \\
\text { product such as log } \\
\text { and other forest } \\
\text { product besides log, } \\
\text { permit to harvest forest } \\
\text { product such as log, } \\
\text { kayu, and the others } \\
\text { besides log (Article } 28 \\
\text { (2)). }\end{array}$ & $\begin{array}{l}\text { HMN } \\
\text { (Rights } \\
\text { of } \\
\text { Control } \\
\text { by the } \\
\text { State ) } \\
\text { (Article } \\
4(1), \\
\text { (2), } \\
\text { Public } \\
\text { Provisio } \\
\text { nal); } \\
\text { State } \\
\text { Forest } \\
\text { Titled } \\
\text { Forest }\end{array}$ & $\begin{array}{l}\text { Ecosystem } \\
\text { unity sych as } \\
\text { lands full of } \\
\text { biological } \\
\text { natural } \\
\text { resources } \\
\text { which are } \\
\text { dominated } \\
\text { by trees in its } \\
\text { natural } \\
\text { environment, } \\
\text { inseparable } \\
\text { one to } \\
\text { another. } \\
\text { Forest areas } \\
\text { are classified } \\
\text { into: } \\
\text { Protected } \\
\text { Forest Area, } \\
\text { Production } \\
\text { Forest Area }\end{array}$ \\
\hline
\end{tabular}

\begin{tabular}{|c|c|c|c|c|c|c|c|c|}
\hline \multirow[b]{2}{*}{$\begin{array}{c}\text { Legislati } \\
\text { on }\end{array}$} & \multicolumn{7}{|c|}{ Yardstick } & \multirow{2}{*}{$\begin{array}{c}\text { SDA } \\
\text { Group }\end{array}$} \\
\hline & $\begin{array}{l}\text { Orientation } \\
\text { (exploitation } \\
\text { or } \\
\text { conservation } \\
\text { ) }\end{array}$ & $\begin{array}{l}\text { Pratiality } \\
\text { (pro- } \\
\text { society or } \\
\text { pro- } \\
\text { capital) }\end{array}$ & $\begin{array}{l}\text { Management } \\
\text { (centralistism decentr } \\
\text { alistism, attirude } \\
\text { toward legal } \\
\text { phralism) and its } \\
\text { implementation } \\
\text { (coordination } \\
\text { sectoral, production } \\
\text { orientation) }\end{array}$ & $\begin{array}{l}\text { Human Rights } \\
\text { Protection } \\
\text { (gender. } \\
\text { recognition of } \\
\text { MHA } \\
\text { (Customary } \\
\text { Law } \\
\text { Community). } \\
\text { dispute } \\
\text { settlement) } \\
\end{array}$ & $\begin{array}{l}\text { Good } \\
\text { govemance } \\
\text { Administratio } \\
\text { n(participation } \\
\text {, transparency } \\
\text { and } \\
\text { accountability } \\
\text { ) }\end{array}$ & $\begin{array}{l}\text { Relationship } \\
\text { berween } \\
\text { people and } \\
\text { SDA (Title } \\
\text { or Permit) }\end{array}$ & $\begin{array}{l}\text { Relation } \\
\text { ship } \\
\text { between } \\
\text { the state } \\
\text { and SDA }\end{array}$ & \\
\hline $\begin{array}{l}\text { Law No. } \\
41 / 1999 \\
\text { on } \\
\text { Forestry }\end{array}$ & $\begin{array}{l}\text { Balancedexp } \\
\text { loitation and } \\
\text { conservation } \\
\text { ("Considerin } \\
\text { g" and } \\
\text { General } \\
\text { Provisional). } \\
\text { Exploitation } \\
\text { (Article 23- } \\
\text { 39) } \\
\text { Conservation } \\
\text { (Article 40- } \\
\text { 51) }\end{array}$ & $\begin{array}{l}\text { Pro- } \\
\text { society in } \\
\text { Konsidera } \\
\text { ns } \\
\text { "Conside } \\
\text { ring" and } \\
\text { Public } \\
\text { Provision } \\
\text { al) but } \\
\text { pro- } \\
\text { capital in } \\
\text { substance } \\
\text { (Article } \\
\text { 27-32) }\end{array}$ & $\begin{array}{l}\text { Centralistic, region is } \\
\text { only operational } \\
\text { (Article } 4 \text { (1), (2), 66, } \\
\text { Public Provisional). } \\
\text { Legal Pluralism (not } \\
\text { regulated). Sectoral } \\
\text { (Ps } 4,6,7,8 \text { etc. } \\
\text { Public Provisional); } \\
\text { specific production } \\
\text { orientation }\end{array}$ & $\begin{array}{l}\text { Gender Equity } \\
\text { (not } \\
\text { regulated), } \\
\text { MHA } \\
\text { Recognition } \\
\text { (only } \\
\text { "noticing the } \\
\text { rghts of MHA } \\
\text { 5 Customary } \\
\text { Forest is } \\
\text { classified into } \\
\text { state forest) } \\
\text { (Article 4(3), } \\
5,17 \text { (2). } \\
37,67 \text {, Public } \\
\text { Provisional). } \\
\text { Dispute } \\
\text { Settlement } \\
\text { (Article 74- } \\
76 \text { ) }\end{array}$ & $\begin{array}{l}\text { Participation, } \\
\text { Transparency, } \\
\text { Accountability } \\
\text { (Article 2, } 11 \\
\text { (2), } 42 \text { (2), } 60 \\
\text { (2), 62, 64, } \\
68-70 \text {, Public } \\
\text { Provisional), } \\
\text { there is } \\
\text { representative } \\
\text { complaint } \\
\text { (Article } 71 \text { - } \\
73 \text { ) }\end{array}$ & $\begin{array}{l}\text { Permit } \\
\text { (Article 26- } \\
\text { 32, Public } \\
\text { Provisional ). } \\
\text { Permit of } \\
\text { loan } \\
\text { agreement } \\
\text { (Article } 38 \\
\text { (2) and (5)). } \\
\text { for example: } \\
\text { business } \\
\text { permit to } \\
\text { urilize forest } \\
\text { product such } \\
\text { as log and } \\
\text { other forest } \\
\text { product } \\
\text { besides log. } \\
\text { permit to } \\
\text { harvest } \\
\text { forest } \\
\text { product such } \\
\text { as log, kayu, } \\
\text { and the } \\
\text { others } \\
\text { besides log } \\
\text { (Article 28 } \\
\text { (2)). }\end{array}$ & $\begin{array}{l}\text { HMN } \\
\text { (Rights } \\
\text { of } \\
\text { Control } \\
\text { by the } \\
\text { State) } \\
\text { (Anticle } \\
4 \text { (1), } \\
\text { (2). } \\
\text { Public } \\
\text { Provisio } \\
\text { nal); } \\
\text { State } \\
\text { Forest } \\
\text { Titled } \\
\text { Forest }\end{array}$ & $\begin{array}{l}\text { Ecosyste } \\
\text { m unity } \\
\text { yych as } \\
\text { lands } \\
\text { full of } \\
\text { biologic } \\
\text { al } \\
\text { natural } \\
\text { resource } \\
5 \text { which } \\
\text { are } \\
\text { dominat } \\
\text { ed by } \\
\text { trees in } \\
\text { its } \\
\text { natural } \\
\text { environ } \\
\text { ment, } \\
\text { insepara } \\
\text { ble one } \\
\text { to } \\
\text { another. } \\
\text { Forest } \\
\text { areas are } \\
\text { classifie } \\
\text { d into: } \\
\text { Protecte } \\
\text { d Forest } \\
\text { Area, } \\
\text { Producti } \\
\text { on } \\
\text { Forest } \\
\text { Area }\end{array}$ \\
\hline
\end{tabular}

Source: Compiler Team of Environmental Sector Program (ESP) 2 the State Ministry of Environmental Afairs and DANIDA

\section{NEGATIVE IMPACTS DUE TO THE DISHARMONY.}


According to Maria S.W. Sumardjono, disharmony in laws and regulations concerning natural resources has caused negative impacts such as destructions and degrading quality of natural resources, injustice and conflicts related to natural resources. ${ }^{7}$ In addition, still according to Maria S.W.Sumardjono, the negative impacts of the disharmony in laws and regulations on the implementation level cause various legal and social problems which eventually lead to riot in legal system, uncertainty and injustice to the. ${ }^{8}$

\section{CAUSE OF DISHARMONY}

Disharmony in the laws regulating the management of the natural resources in Indonesia occurs because all of the laws do not share the same principles even though they regulate the same object; namely, Article 33 paragraph 3 of the Constitution of the republic of Indonesia Year 1945. ${ }^{9}$

\section{EWPOINT OF LEGAL THEORY ON THE DISHARMONY IN LAWS.}

According to Hans Kelsen as quoted by Munir Fuady in his theory; namely, Ranked Legal Norm Theory (Stufenbau Theory) and Basic Norm Theory (Grundnorm), that the laws in a country have to be harmonious one to another, either vertically or horizontally, because according Hans Kelsen, every law in a country has to be derived from one legal ground developing into some some legal principles about jurispruden logics; namely:

6.1. Principle of Derogation, that every legal regulation is derived from higher regulations.

6.2. Non-Contradictory Principle, that there must not any contradictory from one legal regulation to another, so that they have to be harmonious, synchronized, and integrated (principle of integrity).

6.3. Derivative Principle, that the law in the lower level is a part of the law in higher level according to practical deductive principle.

6.4. Systemic Principle, that the legal system which has lower level is a sub-system of the higher laws, so that all prevailing legal regulations are actually a holistic system.

6.5. eneralized Principle, that the higher laws are generalizations of the lower ones, and vice versa, that the lower laws are specificity of the higher ones.

6.6 Principle of reductionism, that the lower laws are reductions from the higher ones.

6.7. Principle of subsumption, that legal regulations have to be included into the higher law group. Thus, they are not derived from another law group. ${ }^{10}$

\section{SOLUTION TO OVERCOME DISHARMONY.}

In order to overcome the problem of disharmony in the regulations of the management of the natural resources in Indonesia, MPR RI command that a new legislation that functions as the main law grounded on the Principle of Natural Resource Management that is determined by MPR RI. The principles are to protect and uphold the integrity of Unitary State of the Republic of Indonesia; to respect and honor human rights; to respect the supremacy of law by accommodating diversity in legal unification; to make prosperous people, particularly through the improvement in the quality of Indonesian human resources; to develop democracy, legal compliance, and transparency and optimalization of people's participation; to realize justice including gender equity in ruling, ownership, using, utilization, and preservation of agrarian/natural resources; to preserve what can provide optimal advantage, either for the present or future generations, by keep paying the attention to capacity and portative power of environment; to execute the social, conservative, and ecological functions in accordance with the local socio-cultural condition; to improve the integration and coordination interdevelopment sector and among regions to implement the agrarian renewal and natural resource management; to acknowledge, respect, and protect the rights of Customary legal community and national cultural diversity over the agrarian/natural resources; to create balance between the rights and obligations of the country, government (central, province, district/regency, and village or else at the same level), society or individual; to implement decentralization such as the authority distribution in the national, provincial, district/regency, and village level, concerning allocation and management of agrarian/natural resources.

\section{REFERENCES}

[1] The Decree of MPR RI is embodied in the Article 5 of the Decree of MPR RI No. IX/MPR/2001 on Agrarian Reform and Management of Natural Resources

[2] Maria S.W. Sumardjono, Kebijakan Pertanahan Antara Regulasi dan Implementasi, Jakarta: Kompas, 2007 , p.35

[3] Maria S.W. Sumardjono, Tanah Dalam Perspektif Hak Ekonomi Sosial Dan Budaya, Jakarta: Kompas, 2008, p. 28

[4] Decree of MPR RI No. IX/MPR/2001 on Agrarian Reform and Management of Natural Resources, Cconsidering part, letter $\mathrm{d}$.

[5] Maria S.W. Sumardjono, et.al., Pengaturan Sumber Daya Alam di Indonesia Antara Yang Tersurat Dan Tersirat, Kajian Kritis Undang-undang Terkait Penataan Ruang dan Sumber Daya Alam, Faculty of 
Law, Gadjah Mada University, collaborating with Gadjah Mada University Press, Yogyakarta, 2011, p. 51.

[6] Ida Nurlinda, Prinsip-Prinsip Pembaruan Agraria Perspektif Hukum, Jakarta: Rajawali Pers, 2009, p. 162

[7] Maria S.W. Soemardjono, Transitional Justice atas Hak Sumber Daya Alam, dalam Komisi Nasional Hak Asasi Manusia : Keadilan Dalam Masa Transisi, Jakarta: Komisi Nasional Hak Asasi Manusia, 2001, p. 21.

[8] Maria S.W. Soemardjono, Menggagas Ulang Penyempurnaan UUPA sebagai Pelaksanaan TAP MPR RI No.IX/MPR/2001 tentang Pembaruan Agraria dan Pengelolaan Sumber Daya Alam, Yogyakarta, 2001, p. 32

[9] Maria S. W. Soemardjono, Agenda Yang Mendesak : Menuju RUU Pengelolaan Sumber Daya Alam Yang Adil, Berkelanjutan, dan Mensejahterakan Masyarakat, Makalah Kerangka Acuan Roundtable Discussion, Yogyakarta, 16 September 2000, p. 14.

[10] Munir Fuady, Teori-Teori Besar Dalam Hukum (Grand Theory), Jakarta: Kencana, 2013, p. 142 